\title{
Influence of Red and Unred Phenotypes of the Coconut Seednuts Colour in Seedbed on the Expression of their Regeneration Level in Seedlings in Nursery, Côte d'Ivoire
}

\author{
Auguste Emmanuel Issali ${ }^{1 *}$, Léonard Kouamé Kouadio ${ }^{1,2}$, \\ Assandé Ahoba ${ }^{3}$, Thierry Tacra Lekadou ${ }^{1}$, \\ Jean Louis Konan ${ }^{1,4}$
}

\author{
1'Station de Recherche sur le Cocotier Port Bouët Marc Delorme, CNRA, 07 BP 13 Abidjan 07, Côte \\ d'Ivoire. \\ 'Université Jean Lorougnon Guédé, BP 150, DALOA, Côte d'Ivoire. \\ ${ }^{3}$ Station SRT, Centre National de Recherche Agronomique (CNRA), 08 BP 33 Abidjan 08. \\ ${ }^{4}$ Centre National de Recherche Agronomique (CNRA), Direction Régionale d'Abidjan, 08 BP 33 Abidjan \\ 08, Côte d'Ivoire.
}

ARTICLE INFO

Article No.: 070916114

DOI: 10.15580/GJAS.2016.7.070916114

\section{Submitted: 09/07/2016}

Accepted: $18 / 07 / 2016$

Published: 05/08/2016

*Corresponding Author Auguste Emmanuel Issali E-mail: issaliemma@yahoo.com

\section{Keywords:}

correlation, nominal variable, notation scale, presence/absence, Chi-square homogeneity test, Chisquare independence test
In order to analyse the influence of the unred and red phenotypes of the seednuts colour and their regeneration level in seedlings, correlations between two nominal variables, namely the nut colour phenotype and its presence or lack within the regenerated seedlings, were tested. Two hundred and twenty four seednuts, whose 87 expressing the red phenotype and 137 the unred one, were buried in seedbed. A scale of notation conferring the note 0 to the red phenotype and 1 to the unred one was adopted. Likewise, in nursery, the same notations 0 and 1 were attributed to red and unred seedlings, respectively. Chi-square Independence and homogeneity non parametric tests at $5 \%$ likelihood were used. Results showed that the numbers of the unred and red phenotypes of the seednuts colour in seedbed were not balanced. This seemed to reveal that the samples did not come from the same parent population. Out of a total of 224 seednuts, 67 showing the red phenotype in seedbed were not able to regenerate in seedlings in nursery. In the same way, 44 seednuts revealing the unred phenotype did not succeed in regenerating in seedlings in nursery. In contrast, from the same number previously reported, 9 expressing the red phenotype in seedbed managed to regenerate in seedlings in nursery. Likewise, 104 seednuts expressing the unred phenotype were not able to regenerate in seedlings in nursery. Thus, the red phenotype was lowly regenerated while the unred one was highly regenerated in seedlings. The link strength between the colour phenotypes and the presence / lack of their regenerated seedlings in nursery, although average, was nonetheless very highly significant. Such a link seems to indicate that the 2 characters depend on an only and same gene pleiotropic. The rest of work, in a near future, will consist in searching for the correlations between the seednut colour phenotypes and the biochemical and physiological processes responsible for germination and regeneration in seedlings. 


\section{INTRODUCTION}

Coconut palm is a perennial, monocotyledonous, diploid and sugar plant of the Arecaceae (Levang, 1988; Guyot, 1992). It grows in intertropical areas. In Cote d'Ivoire, in 2004, 330 million nuts were yielded. Coconut plantations cover 60 thousand hectares. They feed about 23 thousand people essentially based on the coastal region (Assa et al., 2006). Moreover, numerous factors influence germination of nuts in seedbed and their regeneration. Among them, there is the nut colour. Indeed, the nuts from Malayan Red Dwarf (MRD) and Cameroon Red Dwarf (CRD) expressed germination lateness and low regeneration in seedbed (De Nucé et Rognon, 1977). Likewise, it has been observed in seedbed that CRD $\times$ RIT seednuts also known as PB113+ germinate with difficulty. Thus, the red phenotype of the seednuts colour descending from CRD would extend the seednuts germination delay and thus would reduce the rate of their regeneration in seedlings. To understand such a phenomenon, we have conducted the experiment whose results are reported here. This consisted in assessing the influence of red and unred phenotypes of the seednuts colour buried in seedbed on the regeneration rate expression of seedlings in nursery. Thus, the influence of unred and red phenotypes of the seednuts colour on the regeneration rate expression of seedlings in nursery is badly known. The knowledge of the existence of this influence as well as its quantification could allow a better understanding of the germination process in coconut palm. Equally, in the future, correlations could be sought between on the one hand, the red phenotype and germination lateness, as well as on the other hand, between red phenotype and regeneration rate. From this, we postulate that the red phenotype influences the regeneration rate expression of seedlings colour phenotype. The objective of this research was to analyse the influence of the red and unred phenotypes of the seednuts colour in seedbed on the expression of regeneration rate of the colour of seedling phenotypes in nursery.

\section{MATERIALS AND METHODS}

\section{Study site, climate, soil, plant and technical materials}

Experiment was conducted from 20th November, 2014 to 25th March, 2016 at the Marc Delorme Coconut Research Station based on Port Bouët, at Abidjan, in Côte d'Ivoire. It is geographically located between $5^{\circ} 14^{\prime}$ and $5^{\circ} 15^{\prime}$ de North latitude and between $3^{\circ} 54^{\prime}$ and $3^{\circ} 55^{\prime}$ West longitude as well as about $20 \mathrm{~m}$ above sea. Climate is of the equatorial type. Soil is constituted of quaternary sand.

The plant material consisting of 5 individuals which came from open pollinations of standing mother plants of Malayan Yellow Dwarf, West African Tall, Cameroon Red Dwarf, Rennell Island Tall and Malayan Red Dwarf and 2 hybrid genotypes was compared in 2 different experiments conducted at seedbed then in nursery (Table 1). In all, 7 treatments were tested. Here, the treatment is defined here as a level of a factor. Seednuts come from either open pollinations or the assisted ones. They were harvested, transferred and stored in nursery area before burying in seedbed.

Technical material was composed of nylon string, of wood stakes, of hoes, of rakes and of a land surveyor chain $20 \mathrm{~m}$ in length.

Table 1: Plant material used in the experiment PBES99

\begin{tabular}{lcccc}
\hline $\mathbf{N}^{\circ}$ & Individuals & Abbreviation & Treatment & Origin of used seednuts \\
\hline 1 & Malayan Yellow Dwarf & MYD & T1 & Open pollination \\
2 & West African Tall & WAT & T2 & Open pollination \\
3 & Hybrid PB121+ & MYD $\times$ WAT+ & T3 & Assisted Pollination (AP) \\
4 & Cameroon Red Dwarf & CRD & T4 & Open pollination \\
5 & Rennell Island Tall & GRL & T5 & Open pollination \\
6 & Hybrid PB113+ & CRD $\times$ RIT & T6 & Assisted Pollination (AP) \\
7 & Malayan Red Dwarf & MRD & T7 & Open pollination \\
\hline
\end{tabular}

\section{Experimental design and measured variables}

In seedbed and in nursery, the seednuts and regenerated seedlings from nuts were laid out according to Completely Randomised Design. In seedbed, the experimental plot measured $4.62 \mathrm{~m}$ long and $3.92 \mathrm{~m}$ wide. Two consecutive rows of buried seednuts had 0.96 $\mathrm{m}$ spacings. Each row consisted of 7 elementary plots of 4 seednuts. In all, 28 seednuts were buried in each row.
Experimental plot was composed of 56 elementary plots with 224 seednuts.

In nursery, the experimental plot measured 630 $\mathrm{cm}$ in length and $477 \mathrm{~cm}$ of width. The elementary plot had two-seedlings. A bagged seedling represented the experimental unit. This bag had $40.6 \mathrm{~cm}$ in diameter and $40.2 \mathrm{~cm}$ in height. The distance between 2 bags belonging to 2 different elementary plots was $5 \mathrm{~cm}$. The one between 2 consecutive rows was $30 \mathrm{~cm}$. In the first 8 rows 12 bagged seedlings were laid out in 6 
elementary plots. In the last 2 rows, 6 elementary plots were wholly or partly endowed with bagged seedlings by reason of unavailability of seedlings.

Two variable types were measured. These are: i) nominal qualitative variables and ii) quantitative variables. Regarding the former, the unred and red phenotypes of the nuts colour were noted. The note 0 was assigned to the red phenotype, while for the unred one, the note 1 was attributed. As for the latter, the collar girth, the seedling height and the number of appeared leaves were measured. The measuring and metal tapes were used for the first 2 variables, whereas regarding the last variable, the counting was achieved.

\section{Data analysis}

The softwares Excel and SPSS versions 2007 and 22, respectively were used for all statistical analyses. Collected data were subjected to the Chi-square independence and homogeneity non parametric tests. The two was carried out at $5 \%$ likelihood.

\section{RESULTS}

Homogeneity of numbers of the seednuts expressing red and unred phenotypes of the seedlings colour in seedbed and in nursery

In seedbed, 87 seednuts expressed the red phenotype, as against 137 for the unred one. The numbers of the unred and red phenotypes related of the seednuts colour were very significantly different (Table 2). In nursery, 9 seedlings showing the red phenotype of the seedlings colour, as against 137 revealing the unred one, were identified. Here also, significant differences were also observed between the numbers of two colour phenotypes (Table 3 ). In sum, the numbers of unred and red phenotypes of the seednuts and seedlings colour were unbalanced in seedbed and in nursery, respectively.

Table 2: Observed and expected numbers related to the unred and red phenotypes of the seednuts colour in seedbed derived from Chi-square homogeneity test

\begin{tabular}{ccccc|ccc}
\hline Phenotype & Note $^{\star}$ & $\begin{array}{c}\text { Observed } \\
\mathbf{N}^{\star}\end{array}$ & $\begin{array}{c}\text { Expected } \\
\mathbf{N}^{\star}\end{array}$ & Residual $^{*}$ & $\begin{array}{c}\text { Chi- }_{\text {square }^{*}} \\
\text { Red }\end{array} \mathbf{d f}^{*}$ & p-value $^{*}$ \\
Unred & $\mathbf{0}$ & 87 & 112 & -25 & 11.161 & 1 & 0.001 \\
\hline- & Total & 224 & 112 & 25 & - & - & - \\
\hline
\end{tabular}

Legend: Note*: Notation scale composed of 0 , corresponding to red colour of the seednut, and 1, représenting the unred colour of other seednuts put in seednut. Observed $\mathbf{N}$ * : Observed count. Expected $\mathbf{N}^{*}$ : Theorical count. Residual ${ }^{*}$ : Difference between expected and observed counts. Chi-square*: Statistical value of calculated Chi-square. $\mathbf{d f}^{*}$ : Degree of freedom. $\mathbf{p}$-value* Calculated likelihood.

Table 3: Observed and expected counts linked with the unred and red phenotypes of the seednuts colour in nursery from Chi-square homogeneity test.

\begin{tabular}{ccccc|ccc}
\hline Phenotype & Note & $\begin{array}{c}\text { Observed } \\
\text { N }\end{array}$ & $\begin{array}{c}\text { Expected } \\
\mathbf{N}\end{array}$ & Residual & $\begin{array}{c}\text { Chi- } \\
\text { Square }\end{array}$ & df & p-value. \\
\hline Red & 0 & 9 & 56.5 & -47.5 & 79.867 & 1 & $<0.001$ \\
Unred & 1 & 104 & 56.5 & 47.5 & - & - & - \\
\hline- & Total & 113 & - & - & - & - & - \\
\hline
\end{tabular}

Influence of the red and unred phenotypes of seednuts colour on the expression of their regeneration in nursery

Out of a total of 224 seednuts buried in seedbed, 111 were not regenerated in seedlings. Among the latter, 67 $(60.40 \%)$ expressed the red phenotype, as against 44 $(39.60 \%)$ for the unred one. In contrast, from a same total previously reported, 113 were regenerated in seedlings. Among them, $9(8 \%)$ showed the red phenotype, whereas $104(92 \%)$ revealed the unred phenotype. In sum, the red phenotype of the seednuts epidermis appeared to be linked with low number of the seedlings regenerated. In the same way the unred one seemed to be related to high number of seedlings regenerated (Table 4).

Pearson Chi-Square, Continuity Correction, Likelihood Ratio, Linear-by-Linear Association tests, showing the link between the colour phenotypes of seednuts in seedbed and the presence or lack of their seedlings in nursery, were all very highly significant ( $p$ value $<0.001$; Table 5)

The examination of the link intensity between the colour phenotypes of seednuts in seedbed and the 
presence or lack of their seedlings in nursery revealed remains, nonetheless, very highly significant $(p$-value $<$ that this link although average $(0.4<0.553<0.6)$, 0.001).

\begin{tabular}{|c|c|c|c|c|c|}
\hline & & & \multicolumn{2}{|c|}{ Note } & \multirow[b]{2}{*}{ Total } \\
\hline & & & 0 & 1 & \\
\hline \multirow[t]{4}{*}{ Preslack } & & Count & 67 & 44 & 111 \\
\hline & & $\%$ within Lack & $60.40 \%$ & $39.60 \%$ & $100.00 \%$ \\
\hline & & $\begin{array}{l}\text { Count } \\
\% \text { within }\end{array}$ & 9 & 104 & 113 \\
\hline & & Presence & $8.00 \%$ & $92.00 \%$ & $100.00 \%$ \\
\hline
\end{tabular}

Table 5: Significance of link between the colour phenotypes of seednuts in seedbed and the presence or lack of their seedlings in nursery.

\begin{tabular}{cccc}
\hline Test & Value & df & p-value (2-sided) \\
\hline Pearson Chi-Square & 68.575 & 1 & $<0.001$ \\
Continuity Correction & 66.258 & 1 & $<0.001$ \\
Likelihood Ratio & 75.087 & 1 & $<0.001$ \\
Linear-by-Linear & 68.269 & 1 & $<0.001$ \\
Association & & & \\
\hline N of Valid Cases b & $\mathbf{2 2 4}$ & & \\
\hline
\end{tabular}

\begin{tabular}{|c|c|c|c|}
\hline Variable & Test & Value & p-value \\
\hline \multirow{2}{*}{$\begin{array}{l}\text { Nominal by } \\
\text { Nominal }\end{array}$} & Phi & 0.553 & $<0.001$ \\
\hline & Cramer's V & 0.553 & $<0.001$ \\
\hline $\mathrm{N}$ of Valid Cases & & 224 & \\
\hline
\end{tabular}

\section{DISCUSSION}

The influence of the unred and red phenotypes of the seednuts colour on the regeneration level expression of their seedlings in nursery was analysed. Work from De Nucé and Rognon (1977) showed not only the lateness, but also low regeneration of the seedlings from Cameroon Red Dwarf and Malayan Red Dwarf. Our researches, presented here, displayed the link between the colour phenotypes of seednuts in seedbed and the presence or lack of their seedlings in nursery.

The numbers of the unred and red phenotypes of the seedlings and seednuts both in seedbed and in nursery were unbalanced (Tables 2 and 3 ). Such results show that the samples would not come from of a single and same parent (http://epiinfovf.canalblog.com/archives/2011/05/12/2111 6785.html, accessed on March 25th 2016). Such an unbalance imposes reservations in analysis of correlations between the 2 phenotypes of the seednuts colour and their expression within regenerated seedlings.

The red phenotype of the seednuts colour buried in seedbed recorded the highest percentage of unregenerated plants while the unred one showed the highest percentage of regenerated plants. The red phenotype of colour of the nut epidermis seems to link with lethality of seednuts.

The link between the unred and red phenotypes of the seednuts colour and their ability to the regeneration in seedlings was average, but very highly significant (Table 4). This intensity of the link confirms 
the assertion according to which the correlation value does not reflect the strength of link. Sure enough, in our present study, although the link was average, it was nonetheless very highly significant. Moreover, the seednuts colour depends on the mother plant while the one of the regenerated plant derived from of the germ colour and thus of the father plant. Therefore, it concerns the relationship between 2 nominal characters, namely the nut colour and that of germ. They could be controlled by a single and the same gene showing pleiotropic effect.

The unred and red phenotypes of the seednuts colour buried in seedbed influence the seedlings regeneration in nursery (Tables 4, 5 and 6). Sure enough, the red colour is linked with low number of the regenerated seedlings, while the unred one is related to high number of the regenerated seedlings (Table 4). This high number of the red seednuts unregenerated in seedlings confirms our observations in seedbed. Indeed, in Cameroon Red Dwarf $x$ Rennell Island Tall ${ }^{+}$(CRD $x$ RIT) also known as PB113+ hybrid, numerous seednuts do not geminate in seedbed. The allele $R$ controlling character Red present in genome of an ecotype seems to confer it the lateness and low regeneration in seedlings. In De Nucé and Rognon (1977), the seednuts whose the phenotype of the epidermis colour was red both displayed germination lateness and low regeneration in seedlings until 87 days after their burying in seedbed.

In Dwarf ecotypes, the epidermis colour of the young nut come from mother plant. However, both in Dwarf and Tall ecotypes, the colour of the seednut germ comes from the pollen of the father plant. It allows a posterior control of the legitimacy of some controlled pollinations (Bourdeix, 1988). Moreover, germination takes place when the radicle develops over micropyle. It is both biochemical and physiological processes. From a biochemical viewpoint, it concerns hydrolyses of the complex substances in the simple ones. It also concerns cycles of the biosynthesis and degradation designated metabolism. Regarding the physiology, it is about carrying substances from one compartment to another, through the biological membranes. We wish that other works allow the establishing, in a near future, the correlation between the colour phenotypes of the nut epidermis and their regeneration in seedlings as well as between these phenotypes and the biochemical and physiological processes responsible for germination and regeneration in seedlings.

\section{REFERENCES}

Assa R, Konan K, Nemlin J, Prades A, Agbo N, Sié R (2006). Diagnostic de la cocoteraie paysanne du littoral ivoirien. Sci.et nat., 3 (2) : 113-120.

Bourdeix R (1988). Etude du déterminisme de la couleur du germe chez le cocotier Nain. Oléag., 43 (10) : 371-374.

De Nucé de Lamothe $M$ et Rognon F, (1977). Les cocotiers nains à Port Bouët. I.-Nain Jaune Ghana, Nain Rouge Malais, Nain Vert Guinée Equatoriale, Nain Rouge Cameroun, Oléag., 32 (8-9) : 367-374.

Guyot M (1992). Systématique des Angiospermes, référence à la flore du Togo. Presse de l'EDITOGO, pp 172-174.

Levang $P$ (1988). Le cocotier est aussi une plante sucrière. Oléag., 43 (4) : 159-164.

\section{Site web references}

http://epiinfovf.canalblog.com/archives/2011/05/12/21116785.html: The URL leading to the page showing how to make the homogeneity non parametric test. Accessed on March 25th 2016.

Cite this Article: Issali AE, Kouadio LK, Ahoba A, Lekadou TT, Konan JL (2016). Influence of Red and Unred Phenotypes of the Coconut Seednuts Colour in Seedbed on the Expression of their Regeneration Level in Seedlings in Nursery, Côte d'Ivoire. Greener Journal of Agricultural Sciences, 6(7): 234-238, http://doi.org/10.15580/GJAS.2016.8.070916114. 